\title{
Genesis and Classification of Some Soils of the River Nile Terraces: A Case Study of Khartoum North, Sudan
}

\author{
Magboul M. Sulieman ${ }^{1 *}$, Ibrahim S. Ibrahim ${ }^{1}$, Jamal T. Elfaki ${ }^{2}$ \\ ${ }^{1}$ Department of Soil and Environment Sciences, Faculty of Agriculture, University of Khartoum, Shambat, Sudan \\ ${ }^{2}$ Faculty of Agriculture, Nile Valley University, Atbara, Sudan \\ Email: "magboul@uofk.edu
}

Received 10 February 2016; accepted 29 February 2016; published 3 March 2016

Copyright (C) 2016 by authors and Scientific Research Publishing Inc.

This work is licensed under the Creative Commons Attribution International License (CC BY).

http://creativecommons.org/licenses/by/4.0/

(c) (i) Open Access

\begin{abstract}
Soils developed in the alluvium terraces of the River Nile at Khartoum North, Sudan was analyzed in an attempt to classify it as well as to refer them to their origin. Three river terraces comprising nine profiles were selected to cover the physiographic positions. Lack of B horizon and carbonate accumulation were main pedogenic processes in subsurface horizons, whereas orhric epipedon was developed on top soil surface. The microscopic inspection of heavy sand mineralogy indicated that the origin of the sand was the Ethiopian plateau. The most abundant clay mineral was smectite, followed by illite, kaolinite and chlorite. The presences of micas (illite) and chlorite in all studied soil samples might emphasize that these soils were young from the pedological viewpoint and less weathered. The soils of the River Nile terraces at Khartoum North were classified into: Typic Torrifluvents (1st terrace), Entic Haplocambids (2nd terrace) and Typic Haplocambids (3rd terrace). Mineralogy analysis indicated that the Entisols and Aridisols of the River Nile terraces in the study area had the same origin that of the igneous and metamorphic rocks from Ethiopian plateau.
\end{abstract}

\section{Keywords}

Pedogenesis Processes, Ochric Epipedon, River Nile Terraces, Entisols, Aridisols, Ethiopian Plateau

\section{Introduction}

The alluvium deposits along the Blue Nile and River Nile at Khartoum North stretch eastward in a relatively

"Corresponding author.

How to cite this paper: Sulieman, M.M., Ibrahim, I.S. and Elfaki, J.T. (2016) Genesis and Classification of Some Soils of the River Nile Terraces: A Case Study of Khartoum North, Sudan. Journal of Geoscience and Environment Protection, 4, 1-16. http://dx.doi.org/10.4236/gep.2016.43001 
wide strip until the upper sandstone pediplains. These deposits of fine soil materials represent the old, semi-recent and recent alluvial flood plains created by the seasonal flooding of these water courses. As a result of the successive recession of the flooding zone through thousands of years due to the reduction in Nile waters, the active flood plain retreats to its present site at the first terrace leaving old flood plains as older terraces. The provenience of sediments can be traced by heavy minerals, clay mineralogy and particle-size distribution, as well as by element ratios [1] (Herrmann et al., 1996).

Research on the time frame of pedogenic processes is limited, because soil chronosequence studies require constant evaluation of the parent material, topography, climate and vegetation within the time of soil formation for all pedons. Since a long period, soil material in the River Nile has successively risen above the water level, forming sequences of Nile terraces of different ages, allowing the observation of subsequent stages of the soil genesis.

Minerals present in the sand fraction can be taken as criteria to infer the origin of the soil parent materials [2] (Abdel-Ghaphor, 1982). The content and distribution of minerals in soils are good means to estimate the stability of minerals against the weathering processes that occur under different soil conditions [3] (El-Shanawany, 1992). Minerals are indicators of the amount of weathering that has taken place and the presence or absence of particular minerals gives clues as how soil has formed [4] (Schultz, 1989). Moreover, knowledge of clay minerals is important to provide a clear indication of the role played by weathering processes [5] (Miller and Donahue, 1992).

Mineralogical composition of sand and/or clay fraction as well as origin, uniformity and weathering rate in some River Nile alluvial or terrace soils have been investigated by many researchers (e.g., [6] Elwan et al., 1980; [7] Amira et al., 2000; [8] Faragallah and Essa 2004).

The present study aims to: (1) identify the soil minerals of the fine sand fractions (heavy sand mineralogy) and clay fractions (clay mineralogy) in the soil layers or horizons of the different Nile River terraces at Khartoum North, Sudan in an attempt to refer them to their origin if possible (2) classify the soils of the study area by using the American system of soil classification.

\section{Material and Methods}

\subsection{Study Area and Soil Sampling}

The investigated area is part of the perilagoonal belt located in the northeastern part of Khartoum North, Sudan between the River Nile at El Khogalab village (Khartoum North), extending eastwards till the piedmont plain and is located where the grid coordinate is at 451437 to $459503 \mathrm{~N}$ and 1747982 to $1750070 \mathrm{E}$ (Figure 1). The study area falls within the semi arid zone [9] (Van der Kevie, 1973). The average annual rainfall varies from 100 $225 \mathrm{~mm}$. Mean maximum temperature of the hottest months May and June is $40^{\circ} \mathrm{C}$ and $42^{\circ} \mathrm{C}$, respectively. Mean minimum temperature of the coldest month (January) is $13^{\circ} \mathrm{C}-16^{\circ} \mathrm{C}$. According to the Soil Taxonomy [10] (Soil Survey Staff, 2014a), the calculated soil temperature regime is hyperthermic, and soil moisture regime is variable from arridic/torric to ustic depending on local topographical conditions. Nine soil profiles and six augers were chosen to represent the different terraces of the River Nile at Khartoum North, Sudan. Profiles 1, 6 and 7 and augers 1, 4, and 5 represent the very recent (1st terrace) Nile terrace soils. Profiles 2, 5 and 8 and augers 2, 3, and 6 represent the succeeding terrace soils (2nd terrace), whereas, profiles 3, 4 and 9 (P 3, 4, 9) are the intermixing of the alluvial plain and the piedmont (Figure 1). Tundub (Capparis decidua), Seyal (Acacia tortilis), Usher, Musket (Prosopis chilensis), Heglig (Balanites aegypiaca) and Seder (Zizyphus spina-christi) are the predominant species among the natural vegetation [11] (Sulieman et al., 2015). All profiles were located using a global position system (GPS, Model 12 XL Garmin). The map of the study area was created using Arc GIS software version 9.3 (Arc GIS, Esri, USA). The sequence of nine representative profiles was described in the field according to [12] Schoeneberger et al. (2012). A soil sample approximately $1 \mathrm{~kg}$ was collected from each horizon or layer and kept in a plastic bag.

\subsection{Samples Preparation and Analysis}

Soil samples were air-dried $\left(26^{\circ} \mathrm{C} \pm 1^{\circ} \mathrm{C}\right)$ and passed through a $2 \mathrm{~mm}$ mesh sieve to obtain the fine soil fraction. The particles-size distribution of the soil samples was determined by the standard pipette method [13] (Dee and Bauder, 1994) and the textural class was obtained by using the USDA textural triangle [14] (Soil Survey Staff, 


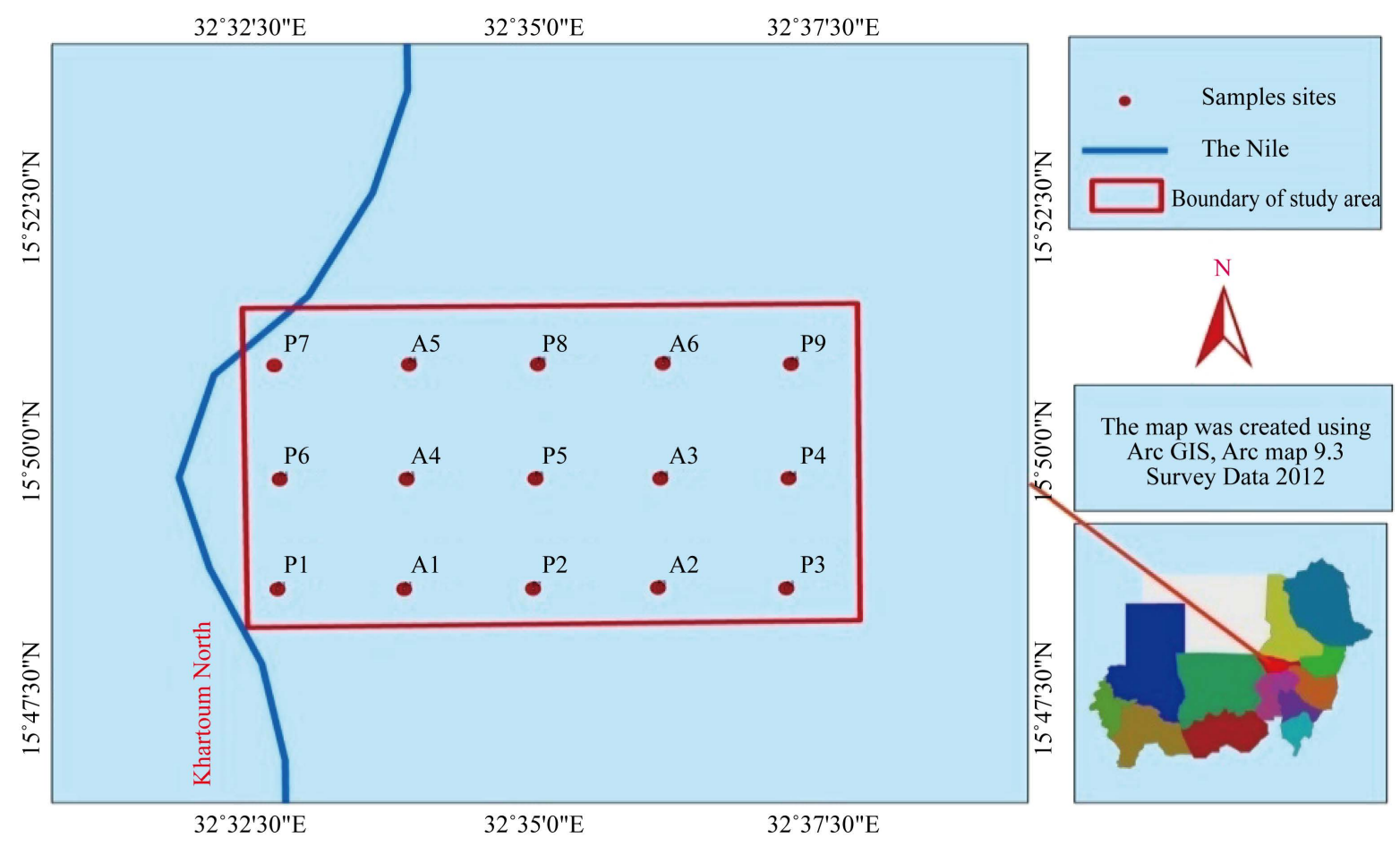

Figure 1. The study area and sites of the soil profiles.

2014b). Soil pH was determined in the saturated soil paste using a digital pH meter model (3510, Jenway). Electrical conductivity (EC) of the saturation paste extraction was determined by using a digital EC meter Model (4510, Jenway). The soluble $\mathrm{Ca}^{2+}$ and $\mathrm{Mg}^{2+}$ were determined by versenate titration method; whereas the soluble $\mathrm{Na}^{+}$and $\mathrm{K}^{+}$were determined by using flame photometer model (Corning 400, USA). The soluble $\mathrm{CO}_{3}^{2-}$ and $\mathrm{HCO}_{3}^{-}$were determined by titration method against $\mathrm{H}_{2} \mathrm{SO}_{4}$, while soluble $\mathrm{SO}_{2}^{2-}$ was determined by using turbidity method [15] (Tabatabai, 1996). Total $\mathrm{N}$ was determined using modified Kjeldahl wet digestion method [16] (Sparks, 1996). The soil organic matter (SOM) was determined by using modified Walkley-Black method [17] (Nelson and Sommers, 1996). Total $P$ was determined using wet digesting method and the absorbance of the solutions were read colorimetric by using spectrophotometer model (Lambda EZ 150, PerkinElmer, USA) according to [18] Olsen and Sommers (1982). Calcium carbonate content $\left(\% \mathrm{CaCO}_{3}\right)$ was determined volumetrically using calcimeter method according to [19] Balázs et al. (2005). The exchangeable sodium percentage (ESP), percentage base saturation (\% BS), and cation exchange capacity (CEC) were determined and calculated according to standard method [16].

Samples of the fine and very fine sand fractions $(25$ - $63 \mu \mathrm{m})$ were separated into heavy and light minerals using bromoform (sp.g. 2.85). Mineral grains were mounted on glass slides using natural Canda balsm (R.I 1.538). Systemic identification and area count of minerals were undertaken using a Zeiss polarizing microscope. These procedures were carried out according to [20] Mange and Maurer (1992). The ratios between some ultra stable minerals were used to evaluate the uniformity, whereas the ratios between less stable and ultra stable minerals were used to evaluate the degree of soil weathering [21] (Hammad, 1968). For clay minerals analysis, the selected samples were pretreatment with oxygen peroxide $\left(30 \% \mathrm{H}_{2} \mathrm{O}_{2}\right)$ to remove organic matter, sodium acetate $(1 \mathrm{~N} \mathrm{NaOAc})$ to remove calcium carbonate, and addition of $1 \mathrm{~N} \mathrm{NaCl}$ to separate the clay from silt and sand, the clay samples $(<2 \mu \mathrm{m})$ were treated with citrate dithionite bicarbonate to remove iron oxide [22] (Mehra and Jakson, 1960). K-saturated clay suspensions was prepared and mounted on glass slides. X-ray diffraction of the parallel-oriented clay specimens was carried out with the X-ray diffractometer Model (XRD, Shimadzu 7000) with $\mathrm{Cu} \mathrm{K} \alpha$ radiation, $45 \mathrm{kV}$ and $35 \mathrm{~mA}$ and scanning range from 2 to 40 Theta. In order to investigate more precisely the mineralogical characteristics of the samples, K-saturated clay specimens were heated at $550^{\circ} \mathrm{C}$ for 2 hours. The interpretations of the clay minerals composition were done according to [23] Dixon and Weed (1989). 


\subsection{Statistical Analysis}

Variations in the soil properties within depths and terraces were statistically analyzed with Turkey's significant difference test for mean separation $(P<0.05)$. All statistical analyses were performed by using statistical package for social science software (IBM SPSS Statistics 16 Core system, IBM Corporation 2012, NY, USA).

\section{Results}

\subsection{Morphological Properties}

The description of the selected representative soil profiles of the three terraces are presented in Table 1. Profile 6 located in the 1st terrace, profile 5 located in the 2nd terrace, whereas, profile 4 located in the 3rd terrace. Almost all profile except Profile 6, were characterized by a horizon sequence $\mathrm{A} / \mathrm{Bw}$ or $\mathrm{A} / \mathrm{Bv}$ suggesting that the soils were young. Soil texture of all profiles belong within four textural classes; loamy sand, sandy clay loam, clay loam and sandy clay. All profiles showed sub-angular blocky structure in the surface horizon and the lower horizons were massive. The quantity of roots in the soil profiles decreased with depth and the boundary between horizons was generally abrupt and wavy.

\subsection{Selected Physico-Chemical Soil Properties}

\subsubsection{Percent Clay, Silt and Sand Content}

Table 2 presents data of percent clay, silt and sand content. The table revealed no significant difference $(P>$ 0.05 ) among depth means of \% clay in the 1st terrace, whereas there was a significant difference between depth $90 \mathrm{~cm}$ and depths 30, 60 and $120 \mathrm{~cm}$ in the 2nd terrace. Similarly, there was a significant difference between depth $30 \mathrm{~cm}$ and depths 60,90 and $120 \mathrm{~cm}$ in the 3rd terrace. The terrace means showed a significant difference $(P<0.05)$ between the 2nd terrace as compared with 1 st and 3rd terraces. The table also showed that the clay content decreased with depth in the 1st terrace, and increased with depth in the 3rd terrace, and was irregularly varied in the 2nd terrace. Insignificant difference $(P>0.05)$ among depth means of \% silt was showed in the 2nd and 3rd terraces, whereas there was a significant difference $(P<0.05)$ between depth $30 \mathrm{~cm}$ and depths 60,90 and 120 $\mathrm{cm}$ in the 1st terrace. The terrace means showed a significant difference $(P<0.05)$ among the three terraces. The silt content decreased with depth in the 3rd terrace, and was irregularly varied in the 1 st and 2nd terraces. Table 2 also revealed no significant difference $(P>0.05)$ among depth means of\% sand in the 3rd terrace, while there was a significant difference $(P<0.05)$ between depth $30 \mathrm{~cm}$ and depth $90 \mathrm{~cm}$ in the 2nd terrace. In contrast, there

Table 1. Selected morphological properties of the three terraces.

\begin{tabular}{|c|c|c|c|c|c|c|c|}
\hline Terrace No. & Horizon & Depth (cm) & Color (moist) & Texture $^{\mathrm{a}}$ (field) & Structure $^{\mathrm{b}}$ & Roots $^{c}$ & Boundary $^{\mathrm{d}}$ \\
\hline \multirow{3}{*}{$\begin{array}{l}\text { First terrace } \\
\text { (Profile 6) }\end{array}$} & $\mathrm{C} 1$ & $0-40$ & $10 \mathrm{YR} 5 / 3$ & SCL & $1 \mathrm{fabk}$ & $2 \mathrm{~m}$ & $\mathrm{CW}$ \\
\hline & $\mathrm{C} 2$ & $40-80$ & $7.5 \mathrm{YR} 4 / 3$ & SCL & $1 \mathrm{fsbk}$ & $2 \mathrm{~m}$ & aw \\
\hline & C3 & $80-142$ & $10 \mathrm{YR} 6 / 3$ & CL & 1 fsbk & $1 \mathrm{~m}$ & aw \\
\hline \multirow{4}{*}{$\begin{array}{l}\text { Second terrace } \\
\text { (Profile 5) }\end{array}$} & A & $0-18$ & $10 \mathrm{YR} 4 / 2$ & SCL & 3fabk & $2 \mathrm{f}$ & aw \\
\hline & $\mathrm{Bk}$ & $18-50$ & $10 \mathrm{YR} 3 / 3$ & SCL & $1 \mathrm{msbk}$ & $2 \mathrm{f}$ & aw \\
\hline & $\mathrm{Ck}$ & $50-90$ & 7.5 YR4/2 & SC & ma & 1 & aw \\
\hline & $\mathrm{C}$ & $90-120$ & $10 \mathrm{YR} 3 / 4$ & SC & ma & 1 & aw \\
\hline \multirow{4}{*}{$\begin{array}{l}\text { Third terrace } \\
\text { (Profile 4) }\end{array}$} & A & $0-10$ & $10 \mathrm{YR} 6 / 3$ & LS & 4fabk & 1 & aw \\
\hline & $\mathrm{Bv}$ & $10-40$ & $10 \mathrm{YR} 3 / 3$ & SCL & $1 \mathrm{msbk}$ & 1 & aw \\
\hline & $\mathrm{BCv}$ & $40-60$ & $10 \mathrm{YR} 3 / 3$ & SC & $1 \mathrm{msbk}$ & 1 & aw \\
\hline & C & $60-114$ & 7.5 YR4/2 & SCL & ma & 1 & aw \\
\hline
\end{tabular}

Texture ${ }^{\mathbf{a}}$; SC: sandy clay; CL: clay loam; SCL: sandy clay loam; LS: loamy sand. Structure ; 1: weak; 2: moderate; 3: strong; 4: very strong; f: fine; m: medium; sbk: subangular blocky; abk, angular block. Roots; ; 1: none; 2: few; 3; moderate; 4: common; f: fine; m: medium. Boundary; a: abrupt; c: clear; w: wavy. 
was a significant difference $(P<0.05)$ between depth $30 \mathrm{~cm}$ and depths 90 and $120 \mathrm{~cm}$ in the 1 st terrace. The terrace means showed a significant difference $(P<0.05)$ between 2 nd terrace as compared with 1st and 3rd terraces. The sand content increased with depth in the 1st terrace, and was irregularly changed in the 2nd and 3rd terraces.

\subsubsection{Soil pH, Electrical Conductivity (EC) and Cation Exchangeable Capacity (CEC)}

Table 3 shows data of $\mathrm{pH}$, EC and CEC values. The table revealed no significant difference $(P>0.05)$ among depth means of $\mathrm{pH}$ values in the 1st and 2nd terrace, while there was a significant difference between depths 30 , $60 \mathrm{~cm}$ and depths 90 and $120 \mathrm{~cm}$ in the 3rd terrace. The terrace means showed a significant difference $(P<0.05)$ between the 1st terrace as compared with the 2 nd and 3rd terraces. The means of $\mathrm{pH}$ values increased with depth in terrace 1 , and were irregularly varied in the 2 nd and 3rd terraces. Significant difference $(P<0.05)$ in EC values was obtained between means of depths $30,60 \mathrm{~cm}$ and depths 90 and $120 \mathrm{~cm}$ in the $1 \mathrm{st}$ and 3rd terraces. However, there was insignificant difference $(P>0.05)$ among depth means in the 2nd terrace. The terrace means showed a significant difference $(P<0.05)$ among the three terraces. Table 3 also showed that the means of EC values decreased with depth in the 1st terrace, whereas they increased in the 2nd and 3rd terraces. Contrary to $\mathrm{pH}$ and EC, no significant difference $(P>0.05)$ in CEC among depth means in the three terraces. However, the terrace means showed a significant difference $(P<0.05)$ between the 2nd terrace as compared with the 1st and 3rd terraces. The CEC values decreased with depth in the 1st terrace, and were irregularly changed in the 2nd and 3rd terraces.

\subsubsection{Percent Calcium Carbonate ( $\left.\% \mathrm{CaCO}_{3}\right)$ and Organic Carbon (\% O.C)}

Table 4 presents data of $\% \mathrm{CaCO}_{3}$ and \% O.C. The table showed no significant difference $(P>0.05)$ among depth means of $\% \mathrm{CaCO}_{3}$ in the 1 st and 3rd terraces, while there was a significant difference between depths 30 ,

Table 2. Variations of percent clay, silt and sand content with depth in the three terraces.

\begin{tabular}{|c|c|c|c|c|c|c|c|c|c|}
\hline \multirow[b]{2}{*}{ Depth (cm) } & \multicolumn{9}{|c|}{ Depth Means } \\
\hline & \multicolumn{3}{|c|}{ \% Clay } & \multicolumn{3}{|c|}{$\%$ Silt } & \multicolumn{3}{|c|}{ \% Sand } \\
\hline 30 & $35.15 \pm 5.56^{\mathrm{a}}$ & $35.14 \pm 1.59^{b}$ & $22.45 \pm 4.42^{\mathrm{b}}$ & $53.17 \pm 3.46^{\mathrm{a}}$ & $13.49 \pm 4.59^{\mathrm{a}}$ & $38.09 \pm 13.26^{\mathrm{a}}$ & $11.67 \pm 2.38^{\mathrm{b}}$ & $51.36 \pm 26.74^{\mathrm{a}}$ & $39.45 \pm 10.41^{\mathrm{a}}$ \\
\hline 60 & $32.76 \pm 4.42^{\mathrm{a}}$ & $35.15 \pm 7.57^{b}$ & $35.14 \pm 3.46^{\mathrm{a}}$ & $34.92 \pm 4.20^{\mathrm{b}}$ & $18.25 \pm 19.77^{\mathrm{a}}$ & $26.19 \pm 3.64^{\mathrm{a}}$ & $32.31 \pm 7.82^{\mathrm{ab}}$ & $46.59 \pm 34.29^{\mathrm{ab}}$ & $38.66 \pm 2.86^{\mathrm{a}}$ \\
\hline 90 & $24.83 \pm 4.83^{\mathrm{a}}$ & $51.81 \pm 2.09^{\mathrm{a}}$ & $38.32 \pm 3.64^{\mathrm{a}}$ & $34.92 \pm 4.20^{\mathrm{b}}$ & $12.69 \pm 3.65^{\mathrm{a}}$ & $22.22 \pm 4.42^{\mathrm{a}}$ & $40.24 \pm 8.36^{\mathrm{a}}$ & $35.49 \pm 35.49^{b}$ & $39.45 \pm 1.59^{\mathrm{a}}$ \\
\hline 120 & $24.83 \pm 4.83^{\mathrm{a}}$ & $44.67 \pm 2.10^{b}$ & $44.74 \pm 0.79^{\mathrm{a}}$ & $34.92 \pm 4.20^{\mathrm{b}}$ & $10.31 \pm 1.27^{\mathrm{a}}$ & $21.43 \pm 3.64^{\mathrm{a}}$ & $40.24 \pm 8.36^{\mathrm{a}}$ & $45.01 \pm 33.16^{\mathrm{ab}}$ & $33.90 \pm 4.20^{\mathrm{a}}$ \\
\hline $\begin{array}{l}\text { Terrace } \\
\text { Means }\end{array}$ & $29.39^{\mathrm{b}}$ & $41.69^{\mathrm{a}}$ & $35.16^{\mathrm{b}}$ & $39.48^{\mathrm{a}}$ & $13.68^{\mathrm{c}}$ & $26.98^{\mathrm{b}}$ & $31.12^{\mathrm{b}}$ & $44.61^{\mathrm{a}}$ & $37.86^{\mathrm{b}}$ \\
\hline
\end{tabular}

Means in each column and row with different letters are significantly different at $P<0.05$.

Table 3. Variations of soil pH, $\mathrm{EC}_{\mathrm{e}}$ and $\mathrm{CEC}$ with depth in the three terraces.

\begin{tabular}{|c|c|c|c|c|c|c|c|c|c|}
\hline \multirow{3}{*}{ Depth (cm) } & \multicolumn{9}{|c|}{ Depth Means } \\
\hline & \multicolumn{3}{|c|}{$\mathrm{pH}$} & \multicolumn{3}{|c|}{ ECe $\left(\mathrm{dS} \mathrm{m}^{1}\right)$} & \multicolumn{3}{|c|}{$\mathrm{CEC}\left(\mathrm{C} \mathrm{mol}+\mathrm{kg}^{-1}\right)$} \\
\hline & Terrace 1 & Terrace 2 & Terrace 3 & Terrace 1 & Terrace 2 & Terrace 3 & Terrace 1 & Terrace 2 & Terrace 3 \\
\hline 30 & $7.61 \pm 0.06^{\mathrm{a}}$ & $7.94 \pm 0.12^{\mathrm{a}}$ & $7.96 \pm 0.04^{\mathrm{a}}$ & $0.98 \pm 0.17^{\mathrm{a}}$ & $0.87 \pm 0.18^{\mathrm{a}}$ & $0.53 \pm 0.18^{\mathrm{b}}$ & $21.66 \pm 0.01^{\mathrm{a}}$ & $27.67 \pm 2.64^{\mathrm{a}}$ & $17.48 \pm 1.74^{\mathrm{a}}$ \\
\hline 60 & $7.66 \pm 0.03^{\mathrm{a}}$ & $7.95 \pm 0.06^{\mathrm{a}}$ & $8.02 \pm 0.11^{\mathrm{a}}$ & $0.73 \pm 0.14^{\mathrm{a}}$ & $1.78 \pm 0.74^{\mathrm{a}}$ & $1.40 \pm 0.34^{\mathrm{b}}$ & $20.00 \pm 0.2^{\mathrm{a}}$ & $25.27 \pm 2.31^{\mathrm{a}}$ & $25.12 \pm 3.33^{\mathrm{a}}$ \\
\hline 90 & $7.73 \pm 0.04^{\mathrm{a}}$ & $7.81 \pm 0.15^{\mathrm{a}}$ & $7.69 \pm 0.11^{\mathrm{b}}$ & $0.50 \pm 0.00^{\mathrm{b}}$ & $3.31 \pm 1.27^{\mathrm{a}}$ & $6.16 \pm 1.04^{\mathrm{a}}$ & $18.75 \pm 2.56^{\mathrm{a}}$ & $26.16 \pm 3.90^{\mathrm{a}}$ & $22.30 \pm 0.85^{\mathrm{a}}$ \\
\hline 120 & $7.73 \pm 0.04^{\mathrm{a}}$ & $7.90 \pm 0.09^{\mathrm{a}}$ & $7.70 \pm 0.08^{\mathrm{b}}$ & $0.50 \pm 0.00^{\mathrm{b}}$ & $3.33 \pm 1.03^{\mathrm{a}}$ & $6.59 \pm 0.6^{\mathrm{a}}$ & $18.75 \pm 2.56^{\mathrm{a}}$ & $29.22 \pm 4.14^{\mathrm{a}}$ & $23.84 \pm 2.82^{\mathrm{a}}$ \\
\hline $\begin{array}{l}\text { Terrace } \\
\text { Means }\end{array}$ & $7.68^{\mathrm{b}}$ & $7.90^{\mathrm{a}}$ & $7.84^{\mathrm{a}}$ & $0.68^{\mathrm{c}}$ & $2.04^{\mathrm{b}}$ & $3.67^{\mathrm{a}}$ & $19.79^{\mathrm{b}}$ & $27.08^{\mathrm{a}}$ & $22.18^{\mathrm{b}}$ \\
\hline
\end{tabular}

Means in each column and row with different letters are significantly different at $P<0.05$. 
$60 \mathrm{~cm}$ and depths 90 and $120 \mathrm{~cm}$ in the 2nd terrace. The terrace means showed insignificant difference $(P>0.05)$ among the three terraces. Meanwhile, the $\% \mathrm{CaCO}_{3}$ increased with depth in the 2nd and 3rd terraces, whereas was irregularly varied in the 1 st terrace. There was no significant difference $(P>0.05)$ among depth means of \% O.C in the three terraces and a cross terraces. The \% O.C decreased with depth in the 1st terrace, whilst were irregularly varied in the 2nd and 3rd terraces.

\subsubsection{Grain Size Analysis}

The grain-size distribution of sand fractions of some studied River Nile terrace soil samples are presented in (Table 5) and their statistical results were illustrated in (Table 6 and Table 7) respectively.

Table 4. Variations of $\% \mathrm{CaCO}_{3}$ and \% O.C with depth in the three terraces.

\begin{tabular}{ccccccc}
\hline & \multicolumn{5}{c}{ Depth Means } \\
\cline { 2 - 7 } Depth $(\mathrm{cm})$ & \multicolumn{5}{c}{ \% $\mathrm{CaCO}_{3}$} & \multicolumn{3}{c}{ \% O.C } \\
\cline { 2 - 7 } & Terrace 1 & Terrace 2 & Terrace 3 & Terrace 1 & Terrace 2 & Terrace 3 \\
\cline { 2 - 7 } 30 & $5.06 \pm 0.331^{\mathrm{a}}$ & $4.44 \pm 0.083^{\mathrm{b}}$ & $4.84 \pm 0.136^{\mathrm{a}}$ & $1.19 \pm 0.339^{\mathrm{a}}$ & $0.96 \pm 0.211^{\mathrm{a}}$ & $1.41 \pm 0.387^{\mathrm{a}}$ \\
60 & $4.59 \pm 0.221^{\mathrm{a}}$ & $4.69 \pm 0.107^{\mathrm{b}}$ & $4.86 \pm 0.533^{\mathrm{a}}$ & $1.06 \pm 0.384^{\mathrm{a}}$ & $0.89 \pm 0.286^{\mathrm{a}}$ & $1.33 \pm 0.293^{\mathrm{a}}$ \\
90 & $4.92 \pm 0.496^{\mathrm{a}}$ & $5.06 \pm 0.211^{\mathrm{a}}$ & $5.21 \pm 0.494^{\mathrm{a}}$ & $0.88 \pm 0.166^{\mathrm{a}}$ & $0.96 \pm 0.4^{\mathrm{a}}$ & $0.98 \pm 0.462^{\mathrm{a}}$ \\
120 & $4.92 \pm 0.496^{\mathrm{a}}$ & $5.45 \pm 0.473^{\mathrm{a}}$ & $5.63 \pm 0.76^{\mathrm{a}}$ & $0.80 \pm 0.244^{\mathrm{a}}$ & $1.09 \pm 0.293^{\mathrm{a}}$ & $1.12 \pm 0.488^{\mathrm{a}}$ \\
Terrace Means & $4.88^{\mathrm{a}}$ & $4.91^{\mathrm{a}}$ & $5.19^{\mathrm{a}}$ & $0.98^{\mathrm{a}}$ & $0.97^{\mathrm{a}}$ & $1.21^{\mathrm{a}}$ \\
\hline
\end{tabular}

Means in each column and row with different letters are significantly different at $P<0.05$.

Table 5. Grain-size distribution of sand fractions of some studied samples.

\begin{tabular}{cccccccc}
\hline $\begin{array}{c}\text { Profile } \\
\text { No. }\end{array}$ & $\begin{array}{c}\text { Depth } \\
(\mathrm{cm})\end{array}$ & $\begin{array}{c}\text { Very Coarse } \\
2.0-1.0 \mathrm{~mm}\end{array}$ & $\begin{array}{c}\text { Coarse } \\
1.0-0.5 \mathrm{~mm}\end{array}$ & $\begin{array}{c}\text { Medium } \\
500-250 \mu \mathrm{m}\end{array}$ & $\begin{array}{c}\text { Fine } \\
250-125 \mu \mathrm{m}\end{array}$ & $\begin{array}{c}\text { Very Fine } \\
125-63 \mu \mathrm{m}\end{array}$ & $\begin{array}{c}\text { Total } \\
(\%)\end{array}$ \\
\hline \multirow{3}{*}{ P1 } & $0-30$ & 0.33 & 0.52 & 1.31 & 2.88 & 6.64 & 11.68 \\
& $30-50$ & 0.95 & 0.95 & 4.25 & 13.71 & 12.45 & 32.31 \\
& $50-80$ & 5.92 & 0.70 & 2.66 & 9.72 & 13.31 & 32.31 \\
& $80-130$ & 7.38 & 0.87 & 3.32 & 12.11 & 16.58 & 40.26 \\
& $0-18$ & 0.75 & 6.26 & 11.75 & 8.28 & 17.17 & 44.21 \\
P5 & $18-50$ & 2.95 & 5.43 & 10.52 & 7.24 & 3.79 & 29.93 \\
& $50-90$ & 0.58 & 2.64 & 7.26 & 8.42 & 11.03 & 29.93 \\
& $90-120$ & 2.09 & 5.80 & 11.56 & 10.30 & 9.70 & 39.45 \\
& $0-15$ & 6.04 & 7.85 & 7.72 & 12.02 & 10.59 & 44.22 \\
P9 & $15-40$ & 5.73 & 6.15 & 6.25 & 5.73 & 6.08 & 29.94 \\
& $40-70$ & 1.45 & 8.95 & 7.96 & 5.24 & 6.33 & 29.93 \\
& $70-120$ & 8.32 & 7.82 & 8.95 & 7.07 & 7.28 & 39.44 \\
\hline
\end{tabular}

Table 6. Variations of very coarse and coarse sand fractions with depth in the three terraces.

\begin{tabular}{ccccccc}
\hline \multirow{2}{*}{ Depth $(\mathrm{cm})$} & \multicolumn{3}{c}{ Depth Means } \\
\cline { 2 - 7 } & \multicolumn{3}{c}{ Very Coarse Sand } & \multicolumn{3}{c}{ Coarse Sand } \\
\cline { 2 - 7 } & Terrace 1 & Terrace 2 & Terrace 3 & Terrace 1 & Terrace 2 & Terrace 3 \\
\hline 30 & $0.33 \pm 0.22^{\mathrm{a}}$ & $0.75 \pm 2.564^{\mathrm{a}}$ & $6.04 \pm 0.726^{\mathrm{a}}$ & $0.52 \pm 0.167^{\mathrm{a}}$ & $6.26 \pm 4.336^{\mathrm{a}}$ & $7.85 \pm 0.463^{\mathrm{a}}$ \\
60 & $0.95 \pm 0.116^{\mathrm{a}}$ & $2.95 \pm 3.31^{\mathrm{a}}$ & $5.73 \pm 2.103^{\mathrm{a}}$ & $0.95 \pm 0.411^{\mathrm{a}}$ & $5.43 \pm 4.12^{\mathrm{a}}$ & $6.15 \pm 1.089^{\mathrm{a}}$ \\
90 & $5.92 \pm 2.525^{\mathrm{a}}$ & $0.58 \pm 0.129^{\mathrm{a}}$ & $1.45 \pm 0.961^{\mathrm{a}}$ & $0.70 \pm 0.254^{\mathrm{a}}$ & $2.64 \pm 7.631^{\mathrm{a}}$ & $8.95 \pm 1.691^{\mathrm{a}}$ \\
120 & $7.38 \pm 2.525^{\mathrm{a}}$ & $2.09 \pm 0.052^{\mathrm{a}}$ & $8.32 \pm 2.103^{\mathrm{a}}$ & $0.87 \pm 0.254^{\mathrm{a}}$ & $5.80 \pm 6.251^{\mathrm{a}}$ & $7.82 \pm 1.529^{\mathrm{a}}$ \\
Terrace Means & $3.64^{\mathrm{ab}}$ & $1.59^{\mathrm{b}}$ & $5.38^{\mathrm{a}}$ & $0.76^{\mathrm{b}}$ & $5.03^{\mathrm{a}}$ & $7.69^{\mathrm{a}}$ \\
\hline
\end{tabular}

Means in each column and row with different letters are significantly different at $P<0.05$. 
Table 7. Variations of medium, fine and very fine sand fractions with depth in the three terraces.

\begin{tabular}{|c|c|c|c|c|c|c|c|c|c|}
\hline \multirow{3}{*}{$\begin{array}{l}\text { Depth } \\
\text { (cm) }\end{array}$} & \multicolumn{9}{|c|}{ Depth Means } \\
\hline & \multicolumn{3}{|c|}{ Medium Sand } & \multicolumn{3}{|c|}{ Fine Sand } & \multicolumn{3}{|c|}{ Very Fine Sand } \\
\hline & Terrace 1 & Terrace 2 & Terrace 3 & Terrace 1 & Terrace 2 & Terrace 3 & Terrace 1 & Terrace 2 & Terrace 3 \\
\hline 30 & $1.31 \pm 0.44^{\mathrm{a}}$ & $11.75 \pm 7.24^{\mathrm{a}}$ & $7.72 \pm 1.746^{\mathrm{a}}$ & $2.88 \pm 1.013^{\mathrm{a}}$ & $8.28 \pm 10.051^{\mathrm{a}}$ & $12.02 \pm 0.463^{\mathrm{a}}$ & $6.64 \pm 6.573^{\mathrm{a}}$ & $17.17 \pm 4.937^{\mathrm{a}}$ & $10.59 \pm 0.44^{\mathrm{a}}$ \\
\hline 60 & $4.25 \pm 1.121^{\mathrm{a}}$ & $10.52 \pm 9.143^{\mathrm{a}}$ & $6.25 \pm 2.127^{\mathrm{a}}$ & $13.71 \pm 3.32^{\mathrm{a}}$ & $7.24 \pm 11.936^{\mathrm{a}}$ & $5.73 \pm 1.376^{\mathrm{b}}$ & $12.45 \pm 5.969^{\mathrm{a}}$ & $3.79 \pm 6.51^{\mathrm{a}}$ & $6.08 \pm 0.939^{b}$ \\
\hline 90 & $2.66 \pm 0.726^{\mathrm{a}}$ & $7.26 \pm 6.19^{\mathrm{a}}$ & $7.96 \pm 0.22^{\mathrm{a}}$ & $9.72 \pm 1.936^{\mathrm{a}}$ & $8.42 \pm 4.113^{\mathrm{a}}$ & $5.24 \pm 1.121^{b}$ & $13.31 \pm 7.269^{\mathrm{a}}$ & $11.03 \pm 5.269^{\mathrm{a}}$ & $6.33 \pm 0.6^{\mathrm{b}}$ \\
\hline 120 & $3.32 \pm 0.726^{\mathrm{a}}$ & $11.56 \pm 6.248^{\mathrm{a}}$ & $8.95 \pm 1.74^{\mathrm{a}}$ & $12.11 \pm 6.936^{\mathrm{a}}$ & $10.30 \pm 6.032^{\mathrm{a}}$ & $7.07 \pm 0.363^{\mathrm{b}}$ & $16.58 \pm 7.269^{\mathrm{a}}$ & $9.70 \pm 5.634^{\mathrm{a}}$ & $7.28 \pm 1.722^{\mathrm{b}}$ \\
\hline $\begin{array}{l}\text { Terrace } \\
\text { Means }\end{array}$ & $2.88^{\mathrm{b}}$ & $10.27^{\mathrm{a}}$ & $7.72^{\mathrm{a}}$ & $9.61^{\mathrm{a}}$ & $8.56^{\mathrm{a}}$ & $7.52^{\mathrm{a}}$ & $12.24^{\mathrm{a}}$ & $10.42^{\mathrm{a}}$ & $7.57^{\mathrm{a}}$ \\
\hline
\end{tabular}

Means in each column and row with different letters are significantly different at $P<0.05$.

\subsubsection{Very Coarse and Coarse Sand Fraction}

Table 6 presents data of very coarse sand (VCS) and coarse sand (CS) fractions. The table showed no significant difference $(P>0.05)$ among depth means of VCS and CS in the three terraces. The terrace means in VSC showed a significant difference $(P<0.05)$ between the 2nd and 3rd terraces. However, significant differences (P $<0.05$ ) were obtained in the CS between the 1st terrace compared with the 2nd and 3rd terraces. The table also revealed that the VCS were irregularly varied with depth in the three terraces; whereas, the CS decreased with depth in the 1st terrace, and was irregularly changed in the 2nd and 3rd terraces.

\subsection{Medium, Fine and Very Fine Sand Fraction}

Table 7 shows data of medium sand (MS), fine sand (FS) and very fine sand (VFS) fractions. The table revealed no significant difference $(P>0.05)$ among depth means of MS fraction in the three terraces. Meanwhile, the terrace means showed a significant difference $(P<0.05)$ between the 1st terrace compared with the 2nd and 3rd terraces. The MS fraction decreased with depth in the 3rd terrace; whereas, was irregularly varied in the 1st and 2nd terraces. Similarly, no significant differences $(P>0.05)$ among depth means of FS and VFS fractions in the 1st and 2nd terraces; while, there was a significant difference $(P<0.05)$ between depth $30 \mathrm{~cm}$ and depths 60,90 and $120 \mathrm{~cm}$ in the 3rd terrace. The terrace means showed no significant difference $(P>0.05)$ among the three terraces. The table also showed that the FS and VFS fractions increased with depth in the 1st terrace, and were irregularly changed in the 2nd and 3rd terraces.

\subsubsection{Mineralogical Composition of the Sand Fractions (Heavy Minerals)}

The microscopic inspection of the Nile terrace soil samples showed that the heavy minerals included; zircon, tourmaline, rutile, garnet, sillimanite, and andalusite. Zircon was observed with several varieties and different forms, sizes and inclusions. Rounded zircon grains were identified in the soil of the 1st and 3rd terrace with range from $2 \%$ to $15 \%$, while sub-rounded and angular zircon grains were observed in the soil of the three terraces with range from $3 \%$ to $47.36 \%$ with irregular abundance throughout the entire soil profile, but decreased far away from the Nile course. Generally, sub rounded to rounded zircon indicated a relatively long distance of transport as well relatively strong reworking. Tourmaline was observed in the three terraces with range from 2.08 to $29 \%$, with irregular distribution throughout the entire soil profiles, but increased far away from the Nile course, suggesting relatively long distance of transport and most probably gneisses and schist source rocks. Rutile was observed in the three terraces with a range from $3 \%$ to $24.99 \%$, with irregular distribution throughout the entire soil profile and from the Nile stream. The presence of the rounded rutile indicated reworked sediments most probably coming from metamorphic source rocks. Garnet was observed in the three terraces with range from $5 \%$ to $67 \%$, with irregular distribution throughout the entire soil profile of the first terrace, while decreased with depth in the second terrace, and increased with depth in the third terrace. The presence of sub rounded to rounded garnet indicated that relatively long distance of transport and most probably coming from metamorphic source rocks. Sillimanite and andalusite were observed in the three terraces with range from $1 \%$ to $50 \%$ and $1 \%$ to $9.09 \%$, respectively with irregular distribution throughout the entire soil profile and from the Nile stream. The 
presence of these minerals indicated reworked sediments and most probably coming from metamorphic source rocks (gneisses and/or schist).

\subsubsection{Zircon, Tourmaline, Rutile Index (ZTR Index)}

Data in Table 8 present the ZTR values. The table revealed that the average zircon, tourmaline and rutile index (ZTR index), was distributed as $54.18 \%, 48.22 \%$ and $36.25 \%$ in 1st terrace, 2nd terrace and 3rd terrace, respectively. ZTR values for ultra-stable minerals less than $75 \%$ mineralogically considered as immature sediments as suggested by [24] (Hubert, 1962). In this context the average ZTR values of the three terraces were characterized by low ZTR index (less than 75\%), suggesting that these sediments are immature mineralogically.

\subsubsection{Mineralogical Composition of the Clay Fraction}

Table 9 shows the semi-quantitative measurements of the identified clay minerals of selected soil samples, and

Table 8. Zircon, Tourmaline and Rutile Index (ZTR Index).

\begin{tabular}{|c|c|c|c|c|c|c|}
\hline Terraces No. & Depth (cm) & Zircon & Tourmaline & Rutile & ZTR Index & Average ZTR \\
\hline \multirow{3}{*}{ 1st Terrace } & $0-30$ & 36.0 & 15.0 & 7.0 & 59.18 & \multirow{3}{*}{54.18} \\
\hline & $30-80$ & 47.36 & 22.79 & 7.01 & 77.81 & \\
\hline & $80-130$ & 15.0 & 5.0 & 3.0 & 25.56 & \\
\hline \multirow{3}{*}{ 2nd Terrace } & $0-18$ & 8.33 & 2.08 & 24.99 & 32.7 & \multirow{3}{*}{48.22} \\
\hline & $18-50$ & 11.67 & 19.47 & 11.68 & 53.59 & \\
\hline & $50-90$ & 5.55 & 15.26 & 18.04 & 59.00 & \\
\hline \multirow{4}{*}{ 3rd Terrace } & $0-15$ & 5.0 & 29.0 & 24.0 & 66.67 & \multirow{4}{*}{36.25} \\
\hline & $15-40$ & 10.0 & 17.0 & 14.0 & 35.65 & \\
\hline & $40-70$ & 4.9 & 21.3 & 6.54 & 30.96 & \\
\hline & $70-120$ & 2.0 & 8.0 & 6.0 & 11.72 & \\
\hline
\end{tabular}

Table 9. Semi-quantitative measurements of the identified minerals in the clay fractions $(<0.002 \mu \mathrm{m})$.

\begin{tabular}{|c|c|c|c|c|c|c|c|}
\hline $\begin{array}{l}\text { Profile } \\
\text { No. }\end{array}$ & Location & $\begin{array}{l}\text { Depth } \\
\text { (cm) }\end{array}$ & $\begin{array}{c}\text { Smectite } \\
14 \AA\end{array}$ & $\begin{array}{c}\text { Illite } \\
10.1 \AA\end{array}$ & $\begin{array}{c}\text { Chlorite } \\
\text { (heat at } 550^{\circ} \mathrm{C} \text { ) }\end{array}$ & $\begin{array}{l}\text { Kaolinite } 1 \text { st } \\
\text { order } 7.15 \AA\end{array}$ & $\begin{array}{c}\text { Kaolinite } 2 \text { nd } \\
\text { order } 3.57 \AA\end{array}$ \\
\hline \multirow{4}{*}{ P 1} & \multirow{3}{*}{ 1st Terrace } & $0-40$ & 88.08 & 4.52 & 2.28 & 1.73 & 0.39 \\
\hline & & $40-80$ & 90.55 & 5.25 & 1.21 & 1.79 & 1.21 \\
\hline & & $80-120$ & 81.99 & 11.37 & 3.2 & 2.58 & 0.87 \\
\hline & \multirow[t]{2}{*}{ Average } & & 86.87 & 7.05 & 2.03 & 2.23 & 0.82 \\
\hline \multirow{4}{*}{ P 5} & & $0-18$ & 89.88 & 1.33 & 1.02 & 0.45 & 0.31 \\
\hline & \multirow{3}{*}{ 2nd Terrace } & $18-50$ & 92.46 & 5.39 & 0.62 & 0.92 & 0.62 \\
\hline & & $50-90$ & 96.82 & 1.77 & 0.41 & 0.60 & 0.41 \\
\hline & & $90-120$ & 93.00 & 2.61 & 2.90 & 0.89 & 0.60 \\
\hline \multirow{6}{*}{ P 8} & Average & & 93.04 & 2.78 & 0.49 & 1.23 & 0.48 \\
\hline & \multirow{4}{*}{ 3rd Terrace } & $0-10$ & 89.06 & 1.56 & 3.49 & 0.53 & 0.36 \\
\hline & & $10-40$ & 87.12 & 1.07 & 4.89 & 2.67 & 0.25 \\
\hline & & $40-60$ & 91.62 & 5.46 & 1.26 & 1.24 & 0.42 \\
\hline & & $60-114$ & 85.95 & 8.19 & 0.63 & 4.64 & 0.63 \\
\hline & Average & & 88.43 & 4.07 & 2.27 & 2.56 & 0.41 \\
\hline
\end{tabular}


the X-ray diffraction patterns are shown in Figures 2-11. The X-ray diffractogram, indicated presence of smectite, illite, kaolinite (1st and 2nd orders), and feldspars as the major clay minerals in the soils of the study area, as confirmed by the presences of d-spacing of $14 \AA, 10.1 \AA, 7.15 \AA$, $3.57 \AA$, and $3.25 \AA$, respectively. Smectite is the most abundant clay minerals in all soil samples with average ranging from $86.87 \%, 93.04 \%$ and $88.43 \%$ in the 1 st terrace, 2nd terrace, and 3rd terrace, respectively. Kaolinite (1st order) was found as $2.23 \%, 1.23 \%$ and $2.56 \%$ in the three terraces, respectively. Illite was obtained as $7.05 \%, 2.78 \%$ and $4.07 \%$ in the 1 st terrace, 2nd terrace, and 3rd terrace, respectively. Chlorite was found as $2.03 \%, 0.49 \%$ and $2.2 \%$ in the three terraces, re-

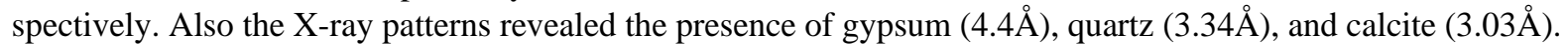

\subsubsection{Soil Classification of the Study Area}

The soils of the three River Nile terraces were classified from soil orders to the sub-great group based primarily on the effect of the soil forming factors on morphological properties of the soils according to the American system for soil classification [10] (Soil Survey Staff, 2014a). Therefore, the soils of the study were classified into: Typic, Torrifluvents (1st terrace soils), Entic, Haplocambids (2nd terrace soils), and Typic, Haplocambids (3rd terrace soils).

\section{Discussion}

The significant difference $(P<0.05)$ in clay content and CEC between 1st and 3rd terraces as compared with the 2nd terrace is contrary to what is expected (increase in\% clay with distance from the River Nile). This could be due to the fact that profiles in the 2nd terrace were in concave sites which received water from runoff and flood. However, the clay content as well as CEC still in the 2nd and 3rd terraces was higher than in the 1st terrace. These present findings were in agreement with [25] Noaman (1989). Significant variation in\% sand conforms to that of the clay content, since these fractions plus silt add to $100 \%$. The significant difference $(P<0.05)$ in soil $\mathrm{pH}$ between the 1st terrace as compared with 2nd and 3rd terraces could be due to less leaching of the basic cations in the upper terraces (2nd and 3rd terraces); whereas in the 1st terrace leaching is expected as the soil is annually flooded [26] (Elfaki et al., 2015). The significant difference $(P<0.05)$ in EC values among the three terraces

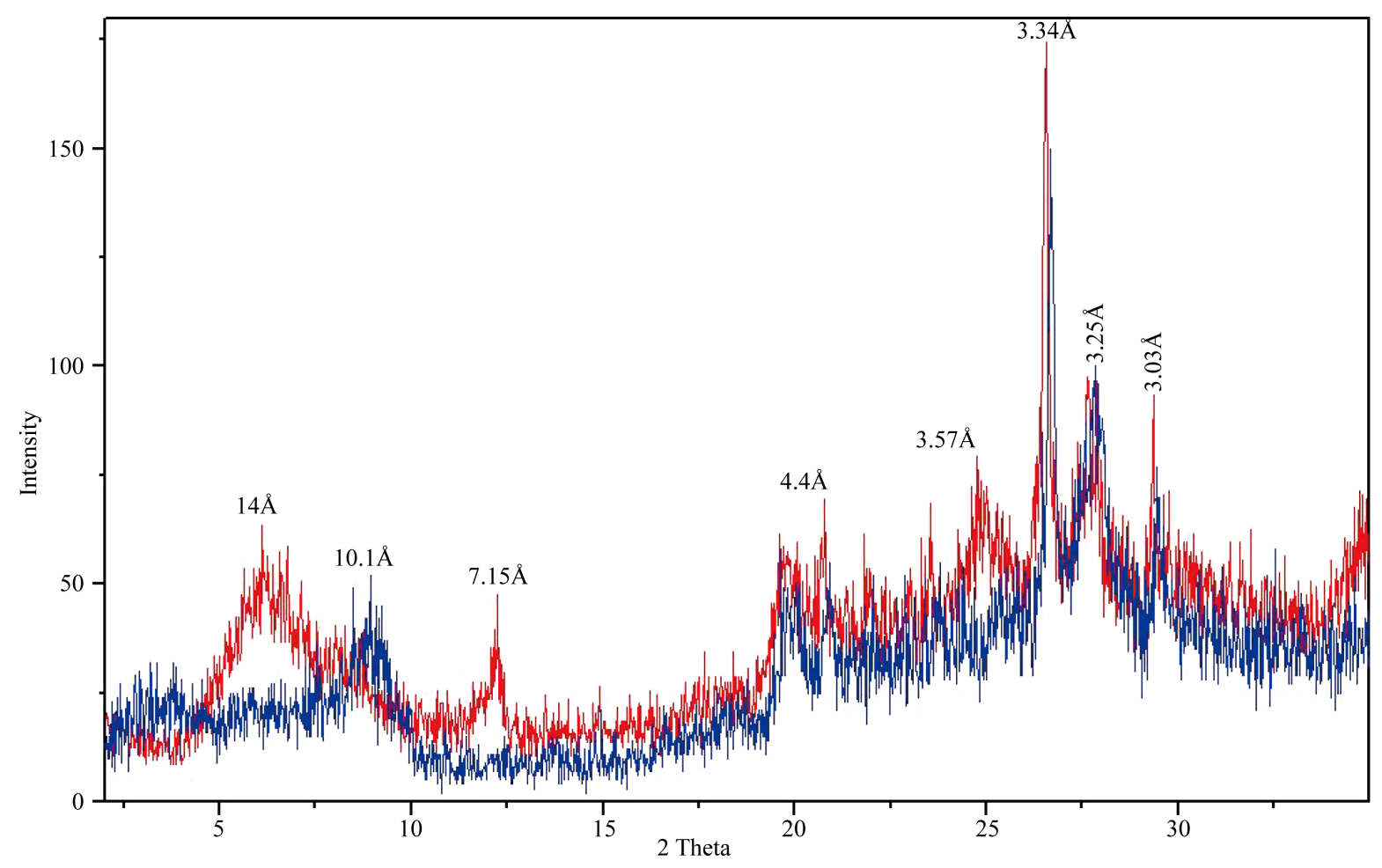

Figure 2. XRD patterns of clay fraction of layer 0 - $40 \mathrm{~cm}$ from profile No. 1(1st terrace); red curve = K-air dry; blue curve $=\mathrm{K}$-air dry + heat at $550^{\circ} \mathrm{C}$. 


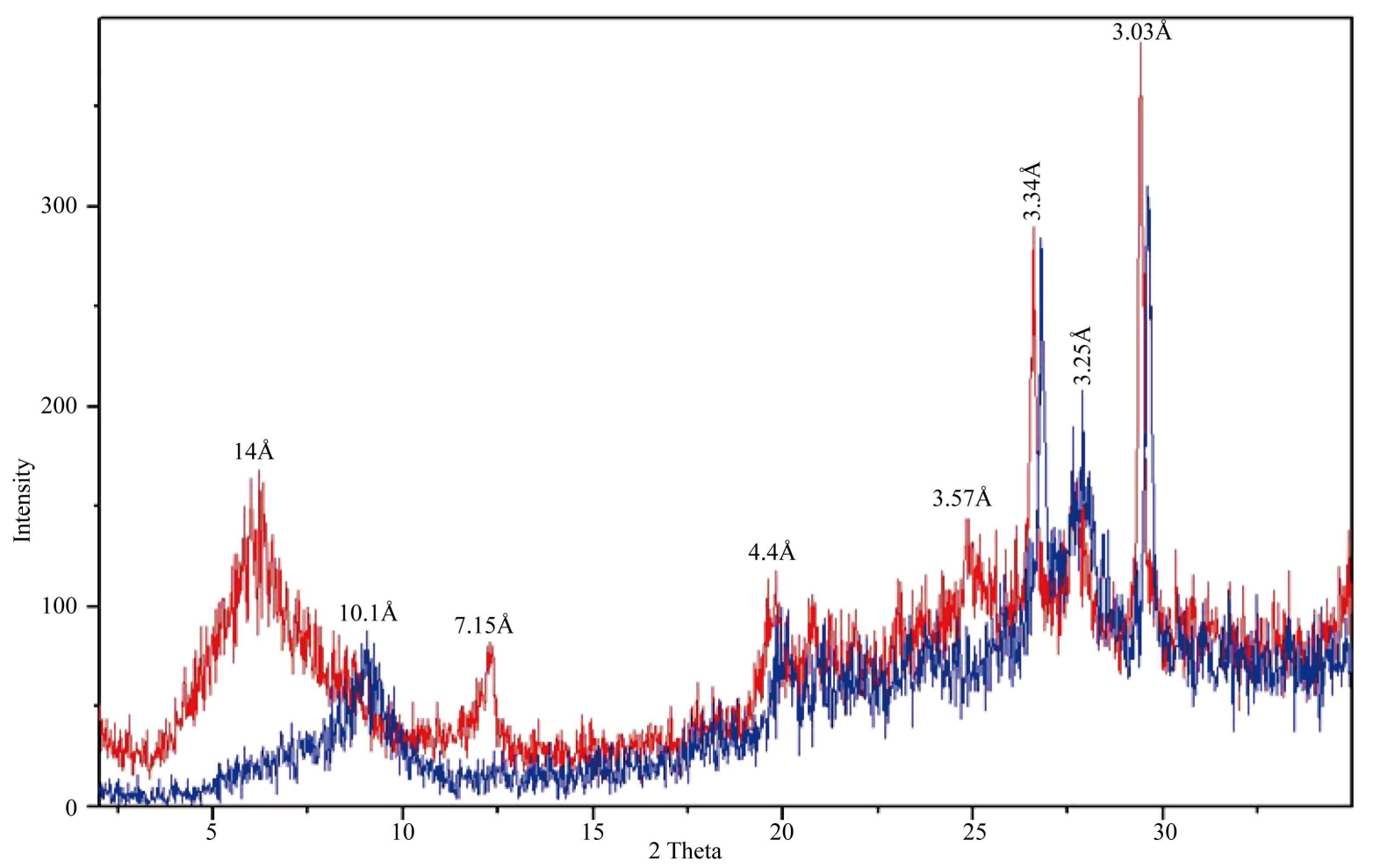

Figure 3. XRD patterns of clay fractions of layer $40-80 \mathrm{~cm}$ from profile No. 1 (1st terrace); red curve = K-air dry; blue curve $=\mathrm{K}$-air dry + heat at $550^{\circ} \mathrm{C}$.

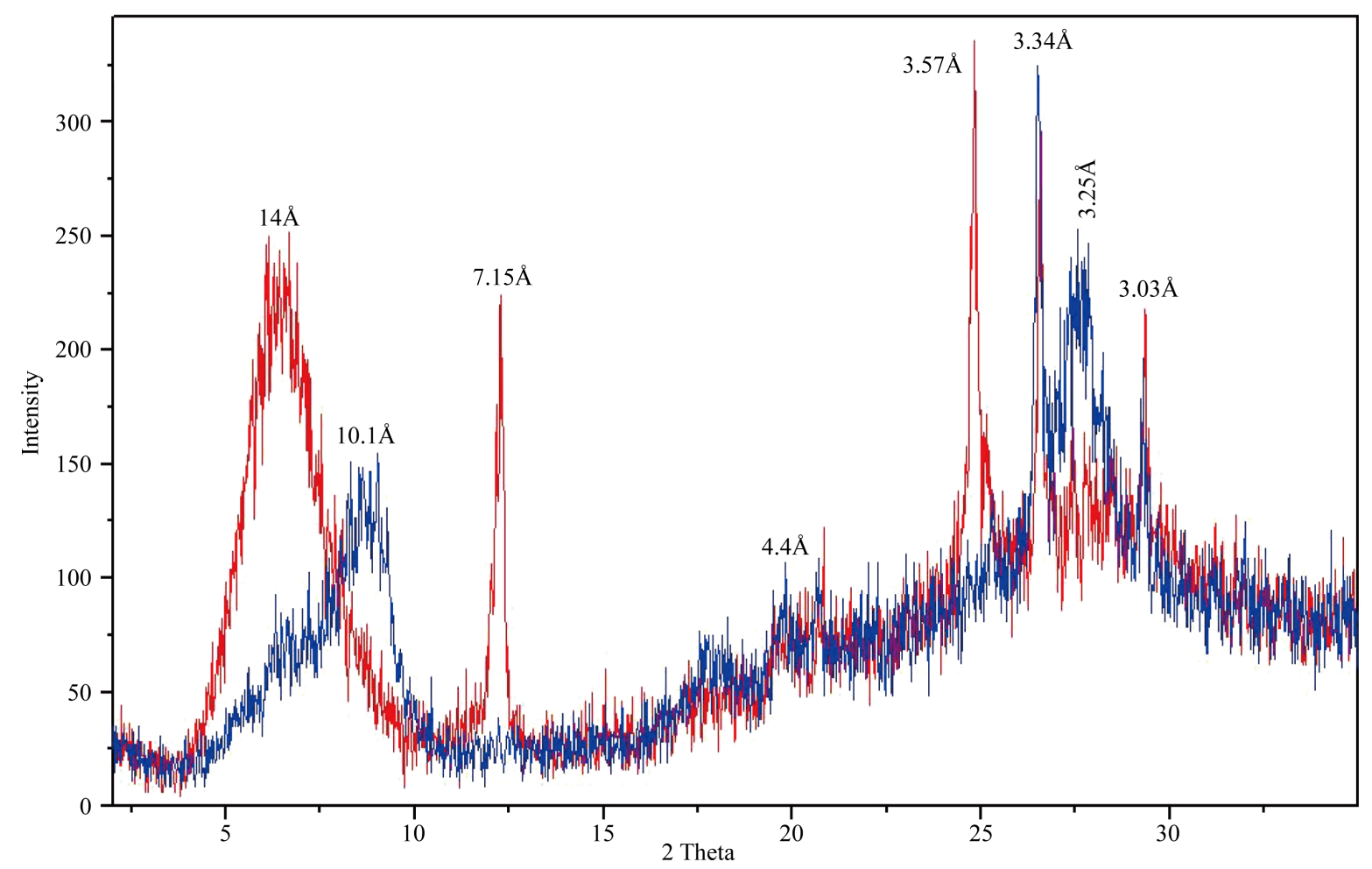

Figure 4. XRD patterns of clay fractions of profile No. 5 from depth 0 - $18 \mathrm{~cm}$ (2nd terrace); red curve = K-air dry; blue curve $=$ K-air dry + heat at $550^{\circ} \mathrm{C}$. 


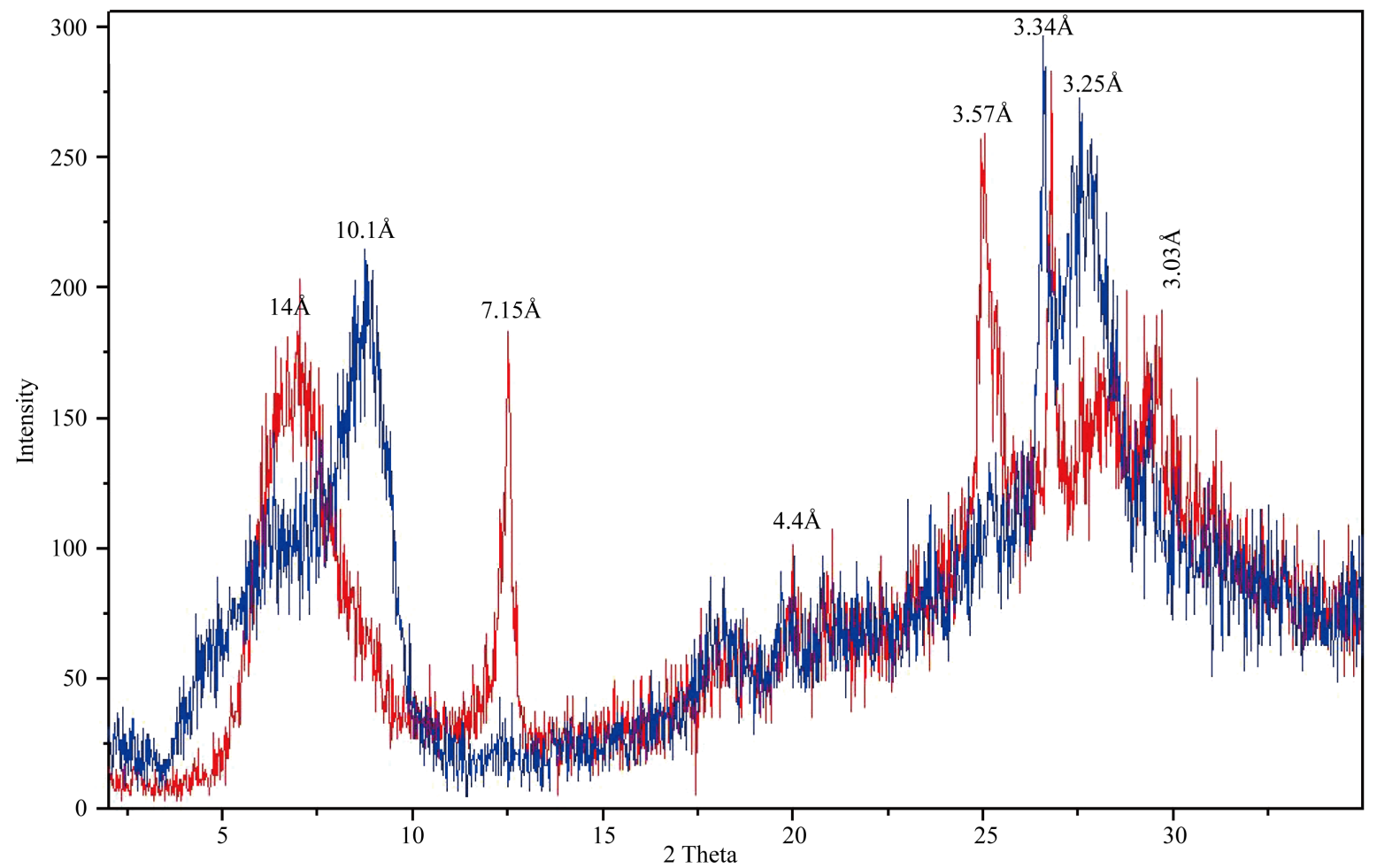

Figure 5. XRD patterns of clay fraction of profile No. 5 from depth 18 - $50 \mathrm{~cm}$ (2nd terrace); red curve = K-air dry; blue curve $=\mathrm{K}$-air dry + heat at $550^{\circ} \mathrm{C}$.

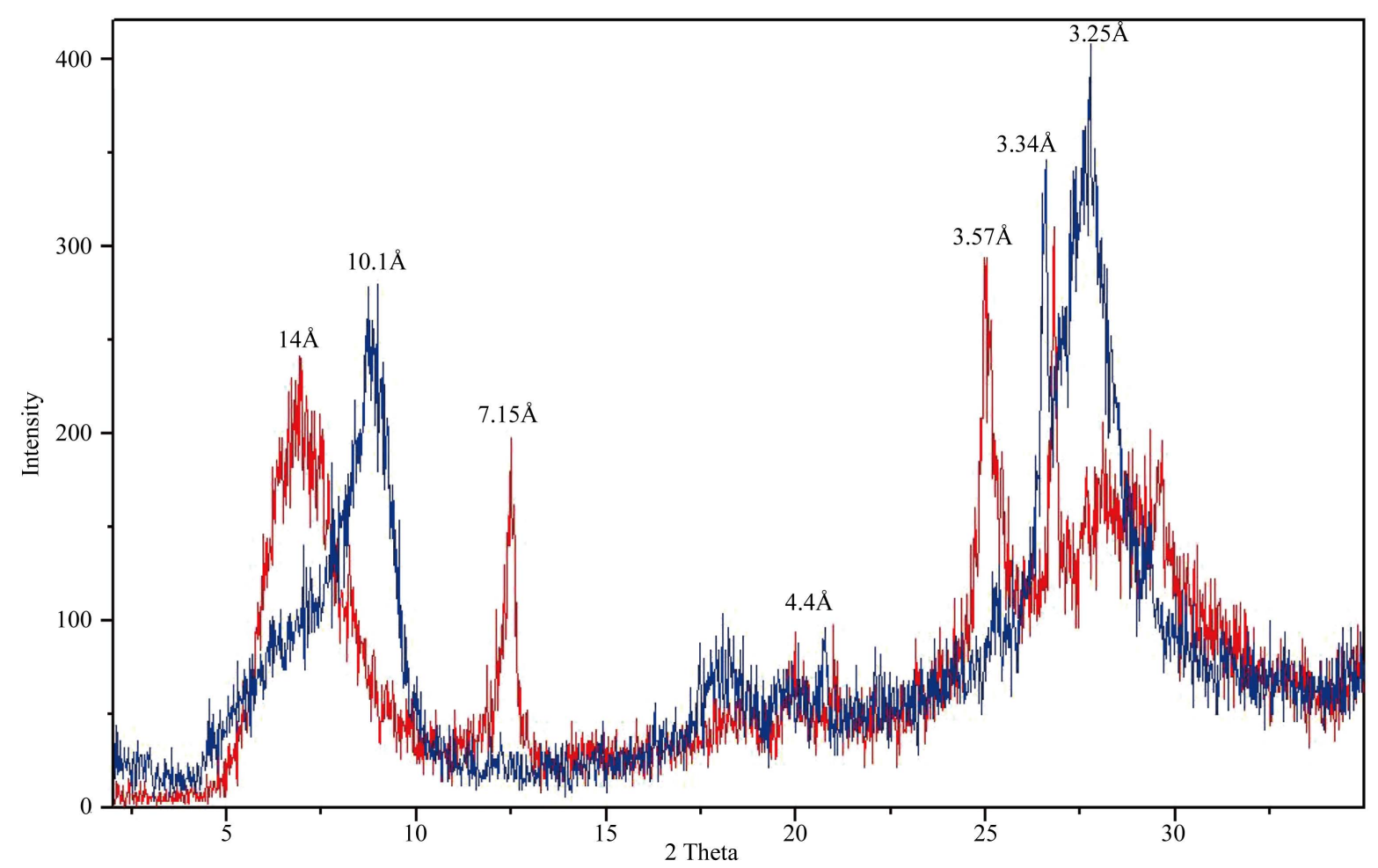

Figure 6. XRD patterns of clay fractions of profile No. 5 from depth 50 - $90 \mathrm{~cm}$ (2nd terrace); red curve = K-air dry, blue curve $=$ K-air dry + heat at $550^{\circ} \mathrm{C}$. 


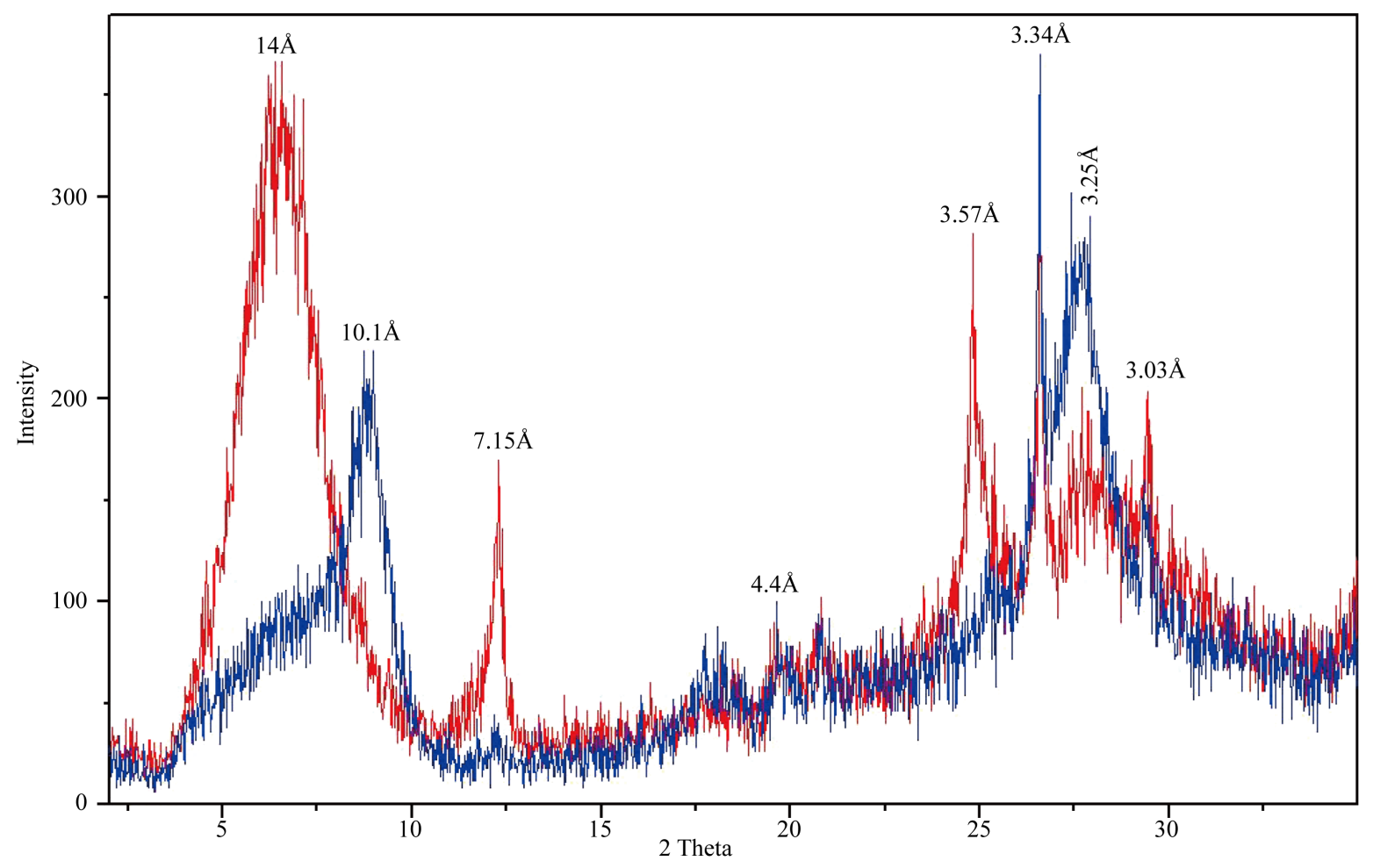

Figure 7. XRD patterns of clay fraction of profile No. 5 from depth $90-120 \mathrm{~cm}$ (2nd terrace); red curve = K-air dry; blue curve $=\mathrm{K}$-air dry + heat at $550^{\circ} \mathrm{C}$.

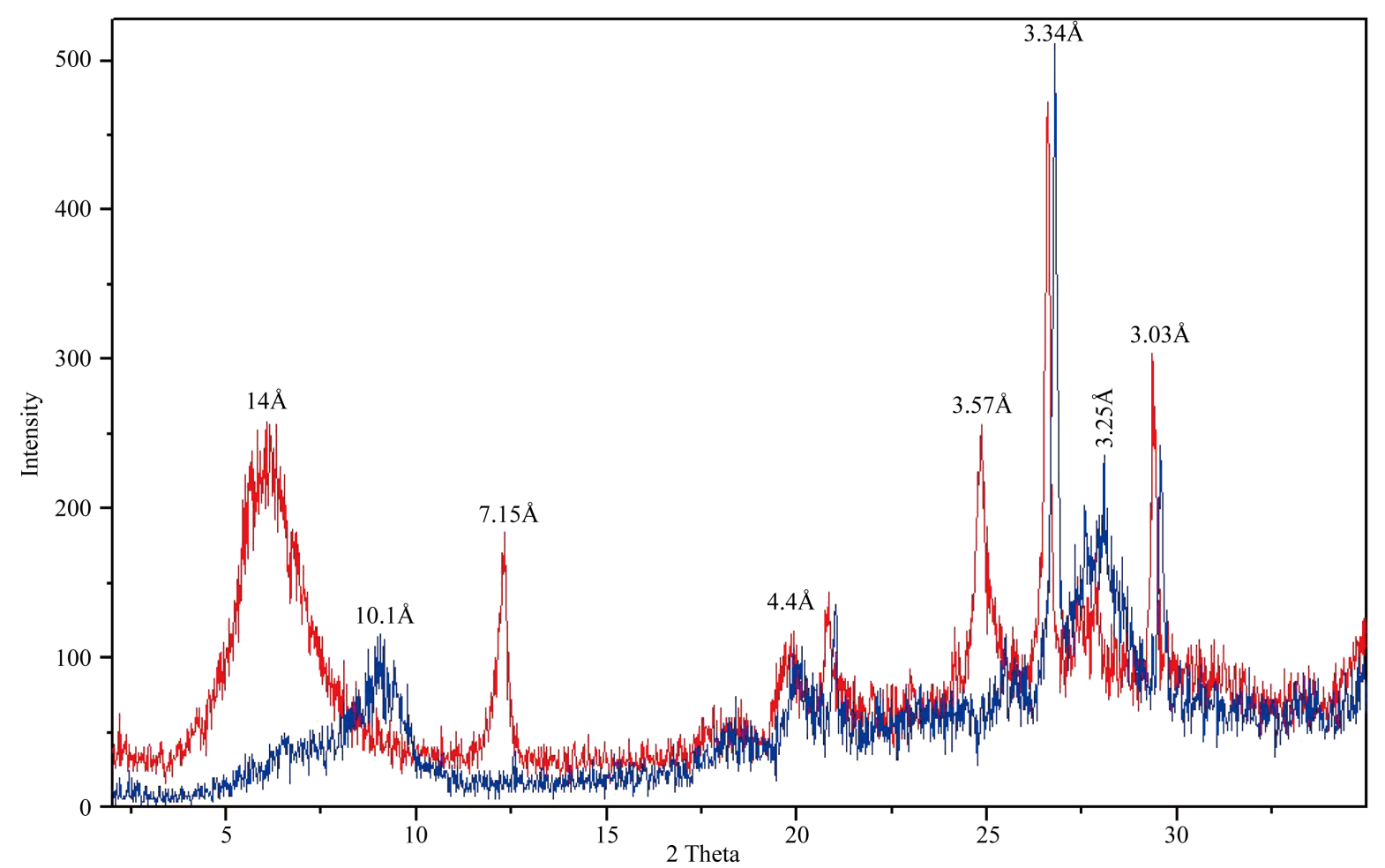

Figure 8. XRD patterns of clay fraction of profile No. 8 from depth 0 - $10 \mathrm{~cm}$ (3rd terrace); red curve = K-air dry; blue curve $=\mathrm{K}$-air dry + heat at $550^{\circ} \mathrm{C}$. 


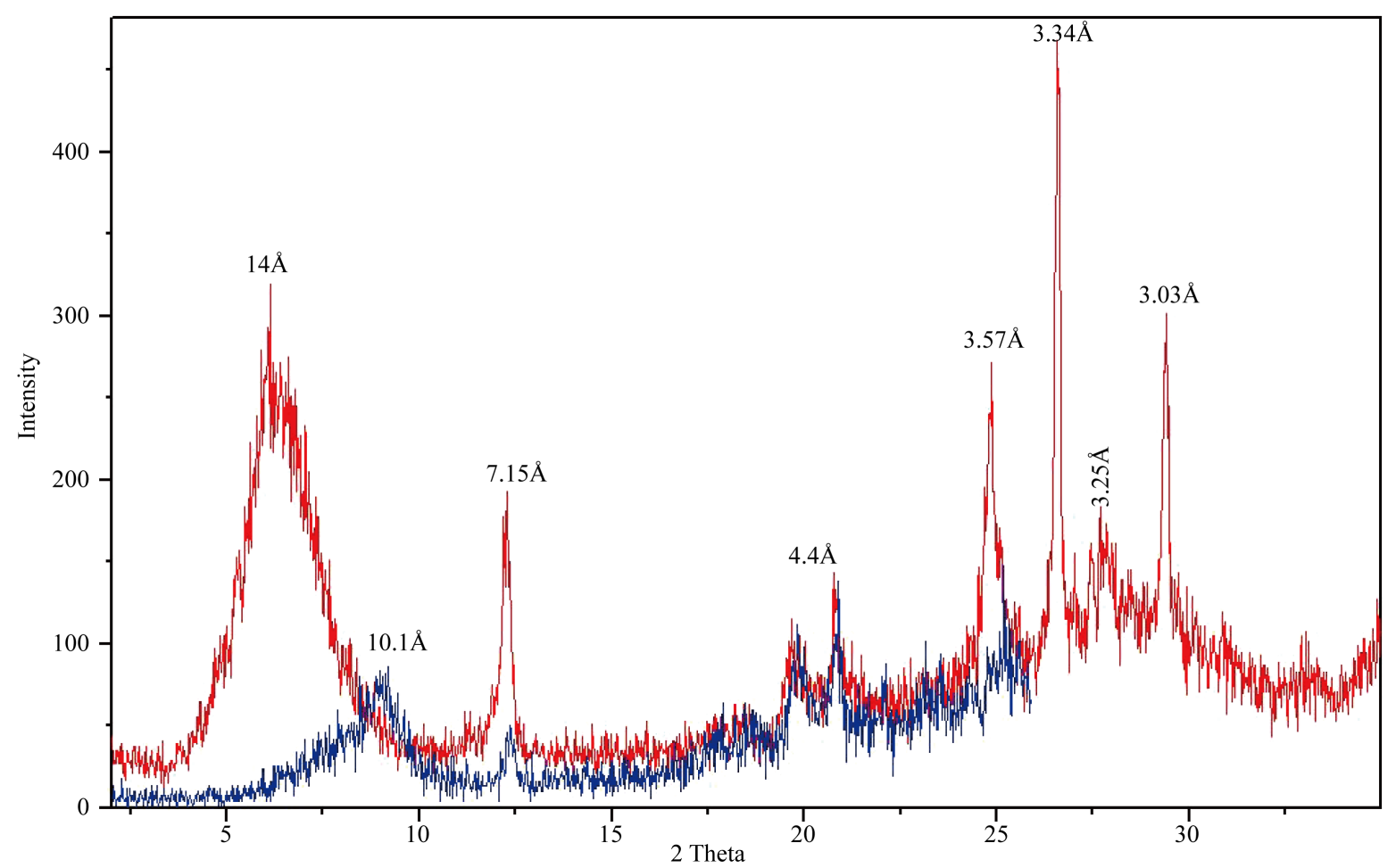

Figure 9. XRD patterns of clay fraction of profile No. 8 from depth $10-40 \mathrm{~cm}$ (3rd terrace); red curve = K-air dry; blue curve $=\mathrm{K}$-air dry + heat at $550^{\circ} \mathrm{C}$.

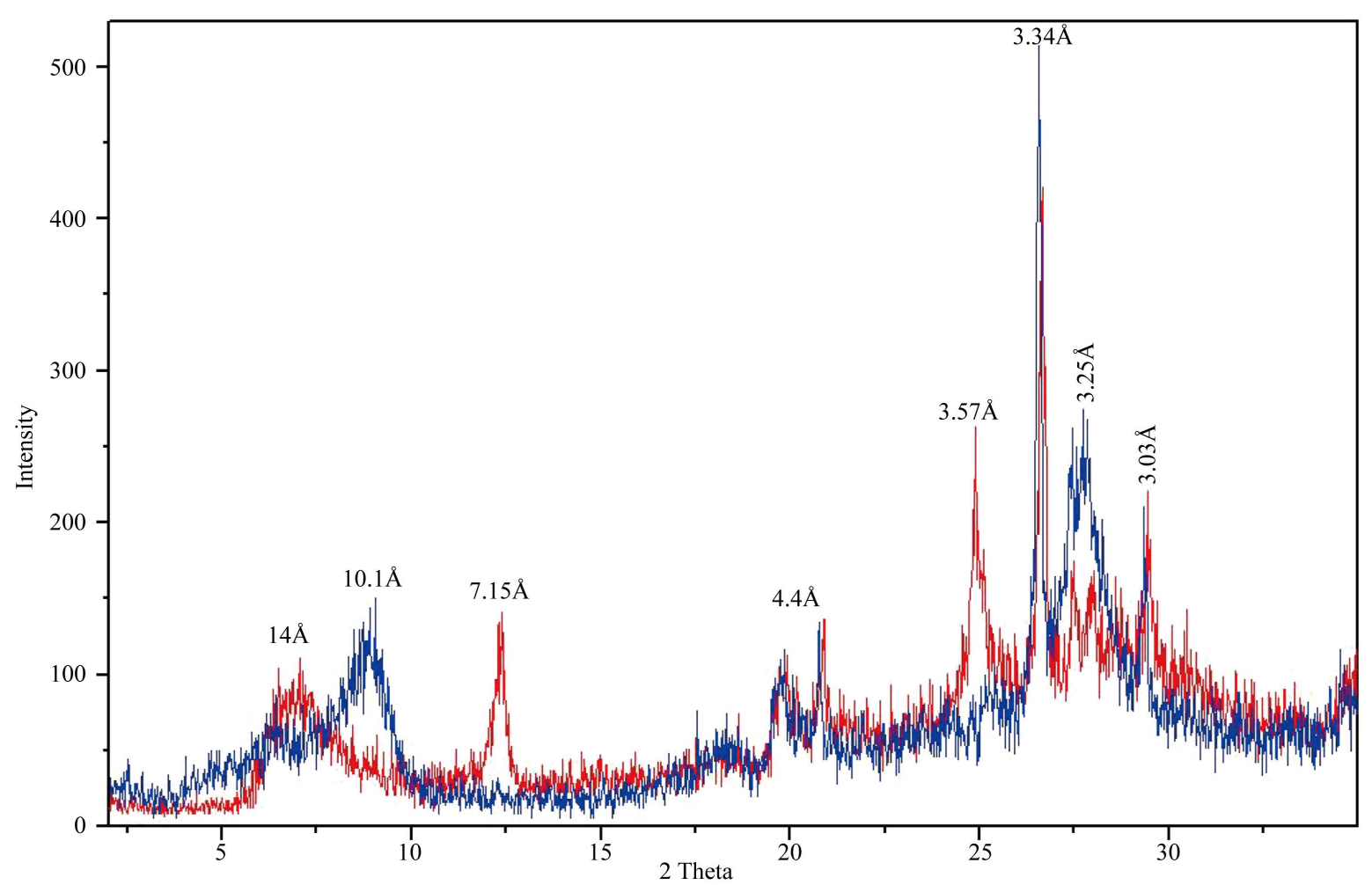

Figure 10. XRD patterns of clay fraction of profile No. 8 from depth 40 - $60 \mathrm{~cm}$ (3rd terrace); red curve = K-air dry; blue curve $=\mathrm{K}$-air dry + heat at $550^{\circ} \mathrm{C}$. 


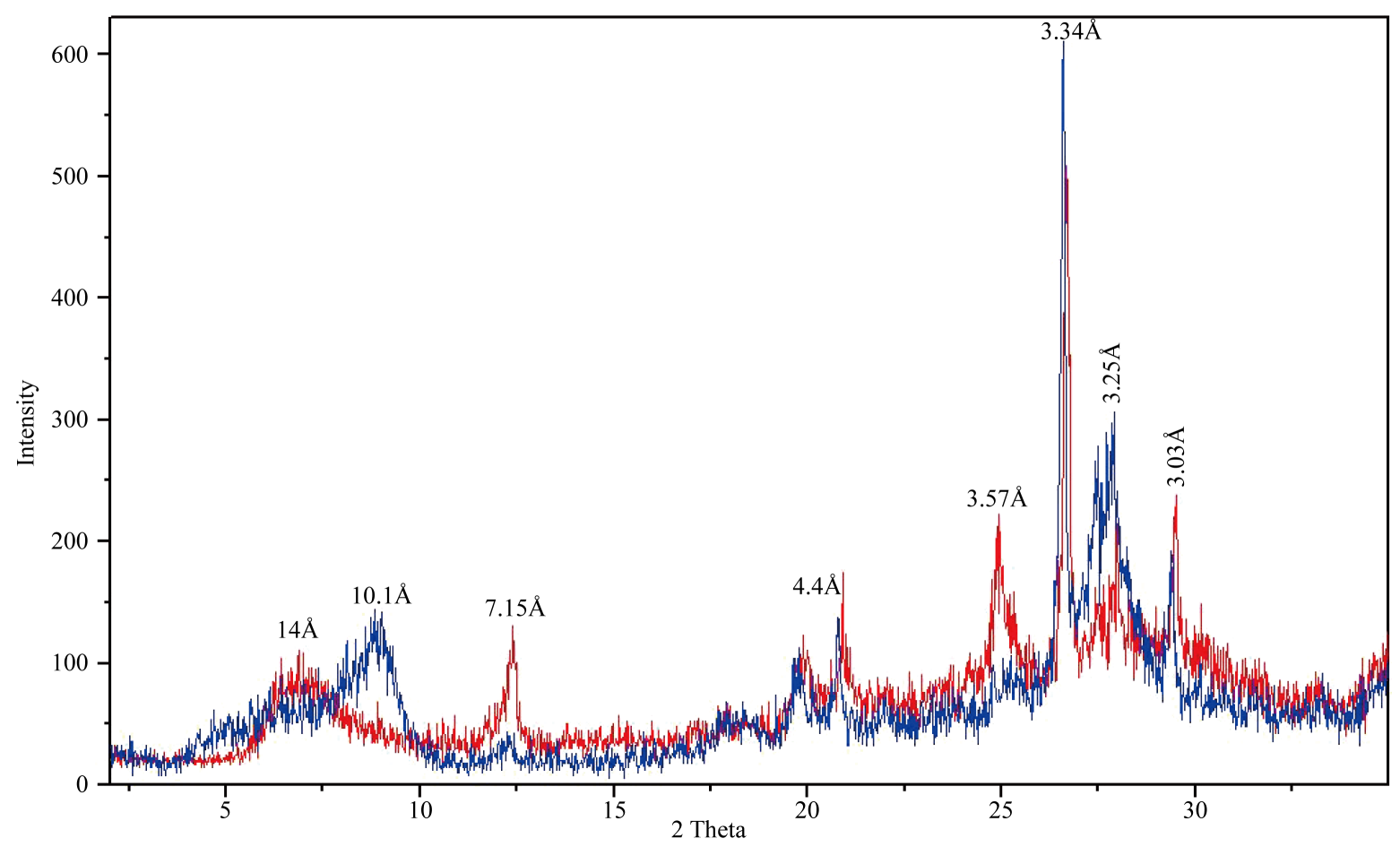

Figure 11. XRD patterns of clay fraction of profile No. 8 from depth 60 - $114 \mathrm{~cm}$ (3rd terrace); red curve = K-air dry; blue curve $=\mathrm{K}$-air dry + heat at $550^{\circ} \mathrm{C}$.

might be due to higher leaching in the 1st terrace as compared with the 2nd terrace, which is inundated only during exceptionally high floods and the 3rd terrace, which had not been inundated for very long period. The variations in percent calcium carbonate $\left(\% \mathrm{CaCO}_{3}\right)$ showed no significant difference $(P>0.05)$ among the three terraces. This could be due to the fact that $\mathrm{CaCO}_{3}$ is less mobile than other salts, i.e. it moves only as $\mathrm{Ca}$ $\left(\mathrm{HCO}_{3}\right)_{2}$ solution salts to be precipitated again when water has evaporated [27] (Elfaki et al., 2016). The significant difference $(P<0.05)$ in the very coarse sand fraction between the 3rd terrace as compared with the 1st and 2nd terraces could be due to its weight, the very coarse sand particles are not flushed back by the receding flood water during soil genesis once transported, they remain there. The same argument could hold in use for the coarse and medium sand fraction. These results were similar to that obtained by [28] Lotefy (1997). The presence of sub rounded and rounded zircon which were irregularly distributed throughout the entire profile and its increases far away from the Nile stream may indicate a relatively long distance of transport as well as relatively strong reworking. The irregular distribution of the tourmaline and rutile throughout the entire profile and their increase far away from the Nile stream may suggest that relatively long distance of transport and most probably gneisses and schist source rocks. These present findings were in agreement with [8] Faragallah and Essa (2004). The presence of same minerals in all terraces could indicate the same origin (igneous and metamorphic rocks) of the soils of the three terraces. The low ZTR index in the study area could be due to prevalence of low energy environment [11] (Sulieman et al., 2015). The high smectite percentage in all terraces might be due to these soils are largely made up of preserved Nile sediments that rich in smectite [29] El-Ameen et al. (2011). Generally, the presence of the different types of clay minerals in the study soils could be due to the detrital origin from the Ethiopian plateau that mixed with the detrital materials derived from the sandstone and limestone plateaus surrounding the Nile river course during the transportation and precipitation of these Nile sediments [11] (Sulieman et al., 2015).

\section{Conclusion}

The present study was conducted in order to investigate the genesis and classification of the soils formed on three River Nile terraces at Khartoum North, Sudan. Based on the findings, it can be concluded that physicochemical, mineralogical and morphological properties of the soils in the investigated area were analogous. 
Presence of ochric epipedon, lack of B horizon and carbonate accumulation were main pedogenic processes in these soils. The analysis of heavy sand mineralogy indicated that the origin of the sand in the study area was the Ethiopian plateau. Mineralogy analysis indicated that the entisols and aridisols of the study area had the same origin that of the igneous and metamorphic rocks from Ethiopian plateau. The soils of the study area were classified as Typic Torrifluvents (1st terrace), Entic Haplocambids (2nd terrace) and Typic Haplocambids (3rd terrace).

\section{Acknowledgements}

The authors are greatly indebted to Associate Prof. Mohammed Salih, Department of Soil and Environment Sciences, University of Khartoum for his kind advice and his help throughout this research.

\section{References}

[1] Herrmann, L., Jahn, R. and Stahr, K. (1996) Identification and Quantification of Dust Additions in Peri-Saharan Soils. In: Guerzoni, S. and Chester, R., Eds., The Impact of African Dust across the Mediterranean: Dordrecht, Kluwer, The Nederlands, 173-182.

[2] Abdel-Ghaphor, E.S.A. (1982) Pedological Studies of Diagnostic Horizons of Some Soils of Egypt. PhD Thesis, Faculty of Agriculture. Al-Azhar University, Egypt.

[3] El-Shanawany, E.A. (1992) Pedological Studies of Some Zone of Encroachment between the Nile Delta and the Desert in Qalubeya Governorate. PhD Thesis, Faculty of Agriculture, Zagazig University, Egypt.

[4] Schultz, D.G. (1989) An Introduction to Soil Mineralogy. In: Dixon, J.B. and Weed, J.B., eds., Minerals in Soil Environments, 2nd Edition, Soil Sci. Am. Madison, Wisconsin, 1-34.

[5] Miller, R.W. and Donhaue, R.L. (1992) Soils. An Introduction to Soils and Plant Growth. Prentice-Hall Inc. Englewood Cliffs.

[6] Elwan, A.A., Harga, A.A., Abd El-Rahman, S.M.H. and Kasem, U.S. (1980) Genesis and Uniformity of Soil Terraces on both Sides of Nile Delta. Egyptian Journal of Soil Science, 20, 99.

[7] Amira, M.S., Shehata, R.B. and Ibrahim, M.A.M. (2000) Pedology, Clay Mineralogy and Classifications of Some Soils Representing the Western Desert Fringes of the Nile Valley in Middle Egypt. Menofia Journal of Agricultural Research, 25, 217-235.

[8] Faragallah, M.A. and Essa, M.A. (2004) Sand and Clay Mineralogy of Some Alluvial Soils with Relation to Soil Origin, Uniformity and Heavy Metals Content, Assiut, Egypt. Egypt Journal of Agriculture, 29, 12.

[9] Van der Kevie, W. (1973) Climatic Zones in the Sudan. Soil Survey Department, Wad Medani.

[10] Soil Survey Staff (2014) Keys to Soil Taxonomy. 12th Edition, United State Department of Agriculture, Natural Resources Conservation Service, Madison.

[11] Sulieman, M., Ibrahim, I., Elfaki, J. and Dafa-Allah, M. (2015) Origin and Distribution of Heavy Minerals in the Surficial and Subsurficial Sediments of the Alluvial Nile River Terraces. Open Journal of Soil Science, 5, 299-310. http://dx.doi.org/10.4236/ojss.2015.512028

[12] Schoeneberger, P.J., Wysocki, D.A., Benham, E.C. and Soil Survey Staff (2012) Field Book for Describing and Sampling Soils, Version 3.0. Natural Resources Conservation Service, National Soil Survey Center, Lincoln.

[13] Dee, G.W. and Bauder, J.W. (1994) Particle-Size Analysis. In: Klute, A., Ed., Methods of Soil Analysis, Part 1. Physical and Mineralogical Methods. Agronomy Monograph No. 9 (2 Edition), American Society of Agronomy/Soil Science Society of America, Madison, 383-411.

[14] Soil Survey Staff (2014) Kellogg Soil Survey Laboratory Methods Manual. In: Burt, R. and Soil Survey Staff, Eds., Soil Survey Investigations Report No. 42 (Version 5.0), United State Department of Agriculture, Natural Resources Conservation Service, Madison.

[15] Tabatabai, M.A. (1996) Sulfur. In: Sparks, D.L., Page, A.L., Helmke, P.A. and Loeppert, R.H. Eds., Methods of Soil Analysis Part 3: Chemical Methods, SSSA, American Society of Agronomy, Madison.

[16] Sparks, D.L. (1996) Methods of Soil Analysis Part 3: Chemical Methods. Soil Science Society of America, American Society of Agronomy, Madison.

[17] Nelson, D.W. and Sommers, L.E. (1996) Total Carbon, Organic Carbon, and Organic Matter. In: Page, A.L., et al., Eds., Methods of Soil Analysis, Part 2, 2nd Edition, American Society of Agronomy, Inc., Madison, 961-1010.

[18] Olsen, S.R. and Sommers, L.E. (1982) Phosphorus. In: Page, A.L., et al., Eds., Methods of Soil Analysis, Part 2, 2nd Edition, American Society of Agronomy, Inc., Madison, 403-431. 
[19] Horváth, B., Opara-Nadi, O. and Beese, F. (2005) A Simple Method for Measuring the Carbonate Content of Soils. Soil Science Society of America Journal, 69, 1066-1068. http://dx.doi.org/10.2136/sssaj2004.0010

[20] Mange, M.A. and Maurer, H.F.W. (1992) Heavy Minerals in Colour. Chapman \& Hall, London, 147. http://dx.doi.org/10.1007/978-94-011-2308-2

[21] Hammad, M.A. (1968) Genesis of the Soils of Western Mediterranean Coast of U.A.R. PhD Thesis, Faculty of Agriculture, Ain Shams University, Egypt.

[22] Mehra, O.P. and Jackson, M.L. (1960) Iron Oxide Removal from Soils and Clays by a Dithionite-Citrate System Buffered with Sodium Bicarbonate. Clays and Clay Minerals, 7, 317-327. http://dx.doi.org/10.1346/CCMN.1958.0070122

[23] Dixon, J.B. and Weed, S.B. (1989) Minerals in Soil Environments. SSSA Book Series. 2nd Edition, Madison.

[24] Hubert, J.F. (1962) A Zircon-Tourmaline-Rutile Maturity Index and Independence of Composition of Heavy Mineral Assemblages with Gross Composition and Texture of Sandstone. Journal of Sedimentary Petrology, 32, 440-450.

[25] Noaman, K.I. (1989) Origin, Mode of Formation and Uniformity of Soil Terraces on Both Sides of Ismailiya Canal, East Delta. Egyptian Journal of Soil Science, 29, 121-131.

[26] Elfaki, J., Gafer, M., Sulieman, M. and Ali, M. (2015) Comparison and Evaluation of Two Analytical Methods for Cation Exchange Capacity and Exchangeable Sodium Percentage of Five Soil Types in Central Sudan. Open Journal of Soil Science, 5, 311-318. http://dx.doi.org/10.4236/ojss.2015.512029

[27] Elfaki, J., Gafei, M., Sulieman, M. and Ali, M. (2016) Assessment of Calcimetric and Titrimetric Methods for Calcium Carbonate Estimation of Five Soil Types in Central Sudan. Journal of Geoscience and Environment Protection, 4, 120-127. http://dx.doi.org/10.4236/gep.2016.41014

[28] Lotefy, I.M.H. (1997) Studies on the Sedimentological and Mineralogical Properties of River Nile Sediments, Upper Egypt. Menofia Journal of Agricultural Research, 22, 259-287.

[29] El-Ameen, A. Farragallah, M. and Essa, M.A. (2011) Sand and Clay Mineralogical Composition in Relation to Origin, Sedimentation Regime, Uniformity, and Weathering Rate of Nile Terrace soils at Assiut, Egypt. Australian Journal of Basic and Applied Sciences, 5, 239-256. 